\title{
Bathymetric distribution, biomass and growth dynamics of intertidal Phyllospadix scouleri and Phyllospadix torreyi in Baja California (Mexico)
}

\author{
P. Ramírez-García ${ }^{1}$, A. Lot $^{1}$, C. M. Duarte ${ }^{2, *}$, J. Terrados ${ }^{2}$, N. S. R. Agawin ${ }^{2}$ \\ ${ }^{1}$ Instituto de Biología, Universidad Nacional Autónoma de México, Apdo. Postal 70-233, Coyoacán 04510, México, D.F. \\ ${ }^{2}$ Centro de Estudios Avanzados de Blanes, CSIC, Camí de Santa Bárbara s/n, E-17300 Blanes, Girona, Spain
}

\begin{abstract}
The bathymetric distribution, biomass, growth dynamics and production of surfgrass species in Baja California (NW Mexico) were examined. The maximum cover of Phyllospadix scouleri (16 $\pm 3.6 \%$ ) was found between 40 and $50 \mathrm{~cm}$ below MLWL (mean low water level), whereas $P$. torreyi showed continuous cover $(100 \%)$ at the lower intertidal ( 80 to $90 \mathrm{~cm}$ below MLWL). Both species showed similar seasonal patterns, with the lowest rate of production of new leaves and biomass observed in April, when the daytime exposure to air of the intertidal area studied was longest. The production of surfgrass was very high, exceeding $8000 \mathrm{~g} \mathrm{DW} \mathrm{m}^{-2} \mathrm{yr}^{-1}$, and the rhizome elongation rate ranged from 0.24 to $0.58 \mathrm{~mm} \mathrm{~d}^{-1}$, resulting in an annual rhizome growth rate of about $8.6 \mathrm{~cm} \mathrm{yr}^{-1}$ The growth and biomass of both species tended to decline with increasing exposure to air during day hours, but this decline was strongest for $P$. torreyi. The leaves of $P$. torreyi desiccated faster than those of $P$. scouleri when exposed to air, and the net photosynthesis rate of $P$. torreyi was more affected than that of $P$. scouleri after being exposed to air for similar lengths of time. The shoot size of $P$. torreyi was more affected than that of $P$. scouleri under the same regime of air exposure. These results suggest that $P$. torreyi is more sensitive to desiccation than $P$. scouleri, and point to both species as the most productive seagrass communities yet studied.
\end{abstract}

KEY WORDS: Growth dynamics Primary productivity Seagrass Phyllospadix Baja California

\section{INTRODUCTION}

Surfgrass (Phyllospadix torreyi S. Watson and Phyllospadix scouleri Hooker) is distributed along the Pacific coast of North America (den Hartog 1970, Phillips 1979), where it grows on rocky substrata exposed to the ocean swell (Ricketts et al. 1985). Phyllospadix species are highly successful colonizers of this habitat, where they are able to competitively exclude other community components, such as macroalgae (Turner 1985).

The American Phyllospadix species have been reported to be bathymetrically differentiated when cooccurring, with $P$. torreyi growing deeper than $P$. scouleri and P. serrulatus (Phillips 1979). The signifi-

\footnotetext{
-Addressee for correspondence. E-mail: duarte@ceab.csic.es
}

cance and generality of this pattern remains, however, to be quantitatively confirmed. The upper limit of the depth distribution of Phyllospadix species is believed to be set by their capacity to resist air exposure during low tides (Phillips 1979, Stewart 1989, Yabe et al. 1996), since carbon incorporation is reduced during emersion (Barbour \& Radosevich. 1979) and the leaves deteriorate when exposed to air and direct sunlight (Phillips 1979, Stewart 1989). These observations suggest that differences in bathymetric distribution among species in the intertidal may reflect, if confirmed, a differential resistance to air exposure.

Although some aspects of the ecology of American surfgrass species are relatively well known, such as their reproductive biology (Stewart \& Rudenberg 1980, Williams 1995), ability to compete for space (Turner 1985, Turner \& Lucas 1985) and nitrogen uptake (Terrados \& Williams 1997), information on their growth 
and production is surprisingly sparse, with no quantitative estimates available as yet. Furthermore, the evaluation of their growth dynamics and production is necessary to assess their potential trophic importance Surfgrass meadows offer refuge to a number of animals, such as lobster (Williams 1995), and are believed to be an important source of carbon for the rich animal food webs inhabiting this coast (Kikuchi 1980).

The goal of this study is 3 -fold: (1) to test the reported bathymetric differentiation of the Phyllospadix species, (2) to quantify their biomass, growth dynamics and production. and their variability in relation to the seasonal variability in tidal range and the associated exposure to air, and (3) to experimentally test differences in the response of the 2 species to exposure to air and the associated desiccation. We achieved this by studying the Phyllospadix species present on the coast of Baja California (Mexico).

\section{METHODS}

The study site (Mesquitito) is located in northern Baja California (Mexico), south of Punta Mesquitito $\left(32^{\circ} 10^{\prime} \mathrm{N}, 116^{\circ} 50^{\prime} \mathrm{W}\right)$, and is characterized by the presence of basaltic platforms that become exposed at low tide and cobble beaches. The climate in the area is temperate with minimum air temperatures $\left(11.2^{\circ} \mathrm{C}\right)$ and maximum precipitation $(58.1 \mathrm{~mm}$ ) in winter (García 1988). The tidal regime is mixed, with a strong semidiurnal component, and with spring low tides occurring during daytime from November to April. The length of the exposure to air of the sustratum during low tide at the $-36 \mathrm{~cm}$ level in the study site, the approximate level where seagrass growth and biomass were recorded, was calculated from a model of tidal dynamics and separated into day and night exposure.

The spatial distribution of surfgrass and other components of the community at the study site is highly patchy. The mosaic of components forming the landscape was described through the estimation of the percent cover of Phyllospadix scouleri, P. torreyi, macroalgae, mussel beds, bare sand and bare rock along 8 transects, each 30 to $60 \mathrm{~m}$ long, haphazardly laid in the study site (3 in February 1997, 3 in April 1997, and 2 in June 1997). The percent cover of the landscape components was estimated, together with sustratum depth, at 1 to $2 \mathrm{~m}$ intervals along each transect using a $30 \times$ $30 \mathrm{~cm}$ grid divided into 9 sections. All transects were referenced to the mean low water level (MLWL; $0 \mathrm{~m}$ ) to provide an absolute representation of the topography and allow their comparison. Differences in cover between surfgrass species at different levels along the intertidal were tested using a 2-way ANOVA with Depth and Species as independent factors.
Biomass, shoot density and leaf growth of both surfgrass species were estimated every 2 mo from October 1996 to August 1997. Temperature and salinity of surface water at the study site were measured every sampling date using an Orion $140 \mathrm{~T}$-S meter. Biomass samples (100 $\mathrm{cm}^{2}, \mathrm{n}=6$ ) of both species were collected haphazardly within the surfgrass patches using a knife to separate the plants from the rock to which they were firmly attached. Sediment and debris were washed from samples and sorted into leaf blades, sheaths, and rhizomes plus roots, and weighed following desiccation at $70^{\circ} \mathrm{C}$ for 24 to $48 \mathrm{~h}$. Because it was difficult to remove inorganic particles from the rhizome plus roots fraction, we combusted these $\left(24 \mathrm{~h}, 400^{\circ} \mathrm{C}\right)$ to estimate the organic weight alone. Shoot density of both species was estimated from shoot counts within 6 replicated $100 \mathrm{~cm}^{2}$ quadrats for each seagrass species placed haphazardly within the surfgrass patches.

Leaf growth was estimated by marking a minimum of 30 shoots in each of the 6 shoot density quadrats by punching 2 colinear holes just below the ligule of the oldest leaf in the shoot. After a time interval of 5 to $7 \mathrm{~d}$ the marked shoots were retrieved, and the number of leaves in the shoots, the length of each leaf blade, the number of new leaves produced during the marking period, and the length of the new portion of the blades grown during the marking period were measured for each shoot. The new portion of each blade was dried at $70^{\circ} \mathrm{C}$ for $24 \mathrm{~h}$, and weighed to estimate leaf production. The leaf plastochrone interval ( $\mathrm{PI}$ in days; Brouns 1985) was calculated for each marking period as

$$
\mathrm{PI}=\frac{\text { number of shoots } \times \text { number of days of marking }}{\text { number of new leaves during the marking period }}
$$

Leaf production (g DW $\mathrm{m}^{-2} \mathrm{~d}^{-1}$ ) was calculated as the product of the average leaf growth rate per shoot ( $g$ DW shoot ${ }^{-1} \mathrm{~d}^{-1}$ ) and shoot density (shoots $\mathrm{m}^{-2}$ ). Sheath production ( $\mathrm{g} \mathrm{DW} \mathrm{m}^{-2} \mathrm{~d}^{-1}$ ) was calculated as the product of the average individual sheath mass ( $\mathrm{g} \mathrm{DW} \mathrm{leaf}^{-1}$ ) and the rate of formation of new leaves per unit area (shoot density $\mathrm{PI}^{-1}$ ).

Rhizome growth rates $\left(\mathrm{mm} \mathrm{d}^{-1}\right)$ were estimated by marking individual rhizomes with a cable tie placed after the second shoot from the rhizome apex, and recording the number of new rhizome internodes and shoots produced after different periods of time. Forty rhizomes of Phyllospadix torreyi were marked in October 1996 but only 9 and 6 rhizomes were retrieved in February and August 1997, respectively (the rest were not found). An additional 20 rhizomes of $P$. scouleri were marked on June 1997 of which only 9 could be found in August 1997. Rhizome production ( $\mathrm{g} \mathrm{DW} \mathrm{m}^{-2}$ $\mathrm{d}^{-1}$ ) was estimated from the product of the average weight of an internode and the total number of new leaves produced per square meter per day, assuming a 
1:1 relationship between the formation of rhizome internodes and new leaves in this genus (Duarte et al. 1994). The estimates of leaf, sheath and rhizome production ( $g$ DW $\mathrm{m}^{-2} \mathrm{~d}^{-1}$ ) obtained in each sampling period were averaged to obtain an estimate of the annual production when multiplied by $365 \mathrm{~d}$. Differences between surfgrass species in biomass, growth rates and production and changes through time were tested using a 2-way ANOVA with Species and Time as independent factors. The overall significance of the correlation between the air exposure during daytime and the different variables describing surfgrass biomass and production was tested by combining the probabilities (p) of the test of significance of each correlation and calculating the amount $-2 \Sigma \ln p$, which has a $\chi^{2}$ distribution (Sokal \& Rohlf 1981).

The effect of air exposure on the desiccation of surfgrass leaves was assessed experimentally by monitoring the weight loss of surfgrass shoots after emersion. Five shoots of each surfgrass species were collected, blotted with paper towels, weighed $( \pm 0.001 \mathrm{~g})$ to determine the initial fresh weight and placed over a rocky platform that had just become exposed to air with the receding tide. The rocky platform was covered with the macroalgal turf characteristic of the area, and some patches of Phyllospadix scoulen were also present. The experimental surfgrass shoots were laid over the rocky platform in a way similar to that adopted by the naturally growing $P$, scouleri shoots when emersed. The experiment was initiated on a clear, sunny day $(8$ March 1998; air temperature: $20^{\circ} \mathrm{C}$ ) at noon, and the weight of each shoot was determined after 1, 2 and $3 \mathrm{~h}$ of air exposure. After $3 \mathrm{~h}$ the shoots were oven dried $\left(24 \mathrm{~h}, 60^{\circ} \mathrm{C}\right)$ to estimate their dry weight. The degree of desiccation achieved by each shoot during the experiment was expressed as the ratio of the desiccation achieved by the shoots after been dried in the oven following the equation

$$
\text { desiccation ratio }=\frac{\text { initial fresh weight }- \text { weight at time } t}{\text { initial fresh weight }- \text { dry weight }}
$$

Differences between surfgrass species in the degree of desiccation achieved after 1,2 and $3 \mathrm{~h}$ were tested using 2 -sample $t$-tests.

The effect of air exposure on surfgrass photosynthesis was assessed experimentally by estimating the net photosynthesis rate of portions of shoots desiccated to different degrees. Surfgrass shoots were cut $4 \mathrm{~cm}$ below the ligule of the oldest leaf, senescent or heavily epiphytized tissues were discarded, and the remaining leaves were gently cleaned of epiphytes. Desiccation of shoots prior to photosynthesis measurements was performed by exposing the shoots to air and direct sunlight over a seawater-soaked towel to emulate the natural conditions experienced by surfgrass shoots when exposed to air during low tide. Different degrees of desiccation were achieved by changing the duration of the air exposure (between 15 and 90 min depending on the experiment). The degree of desiccation experienced by each shoot was calculated from the weight loss shown by the shoot during the desiccation treatment as described previously. After the desiccation treatment the shoots were reimmersed in seawater for $2 \mathrm{~h}$ before the photosynthesis measurements started to allow the rehydration of leaf tissues.

Net photosynthesis rates were estimated from the changes in concentration of dissolved oxygen after a $1 \mathrm{~h}$ incubation of chambers containing 1 surfgrass shoot. The incubation chambers were $260 \mathrm{ml}$ glass bottles which were hung from a line that ran $30 \mathrm{~cm}$ below the sea surface at the study area. Ambient daylight (between 174 and $1055 \mu \mathrm{mol} \mathrm{m} \mathrm{m}^{-2} \mathrm{~s}^{-1}$ inside the incubation bottles) and temperature (between 17 and $19^{\circ} \mathrm{C}$ ) were used in the incubations. Waves maintained the incubation chambers in continuous motion; further stirring inside the chambers was obtained through the movement of a small glass rod hanging inside each chamber. Oxygen concentrations were determined using an Corning Check Mate M90 oxygen meter. Three shoots (replicates) of each species were used for each desiccation treatment and incubation. In addition, 3 shoots which were not desiccated were incubated under the same conditions as those desiccated to account for the effect of desiccation on net photosynthesis for each species and experiment. Two incubation chambers were filled with seawater and incubated in the same way as those containing surfgrass shoots to control for plankton metabolism in each experiment. All the experiments were performed between 10 and 14 March 1998. The average net photosynthesis rate of the desiccated shoots in each experiment was divided by the average net photosynthesis rate of the control, undesiccated shoots (i.e. standardized net photosynthesis rate) to make the results of the different experiments comparable. The effect of air exposure on surfgrass photosynthesis was modelled through linear regression of the standardized net photosynthesis rates versus the duration of the exposure to air during the desiccation treatments. Differences between species in the effect of desiccation were tested by comparing the slopes ( $t$-test, $p<0.05$ ) of the corresponding regression lines.

Differences in the effect of air exposure on shoot size between Phyllospadix scouleri and P. torreyi were assessed by relocating boulders which were naturally colonized by surfgrass to a higher elevation in the intertidal zone. On 10 March 1998, 6 boulders colonized by each surfgrass species were selected from the subtidal zone and 3 of them were haphazardly selected and anchored at the level of a large intertidal $P$. scouleri 
patch growing at an elevation where $P$. torreyi does not occur. Extreme care was adopted to place the surface of the boulders colonized by surfgrass at the same level of the sustratum of the intertidal $P$. scouleri patch. The other 3 boulders of each species were anchored at a subtidal elevation 4 to $5 \mathrm{~m}$ away from the intertidal $P$. scouleri patch where $P$. torreyi is the dominant species. Before placing the boulders at the desired locations, 10 shoots growing on each boulder were haphazardly collected for measurements. The length of the longest leaf, the number of standing leaves, the leaf width, and the biomass (g DW, after drying at $100^{\circ} \mathrm{C}$ for $24 \mathrm{~h}$ ) were estimated for each shoot. After 77 d (26 May 1998) the boulders were located and between 21 and 33 shoots were haphazardly collected from each of them and similar measurements were performed. The effect of air exposure on the shoot morphological features of each species was tested using 2-way ANOVA with Time (Initial, Final), and Exposure (Subtidal, Intertidal) as independent factors.

\section{RESULTS}

The studied area showed a complex topography (Fig. 1) that led to considerable small-scale (a few meters) patchiness in the components of the landscape. Surfgrass occurred in the upper portions of the site as patches (median diameter, $18 \mathrm{~cm}$ ), and as more extensive meadows in the lower portions. Examination of the bathymetric distribution of the components of the

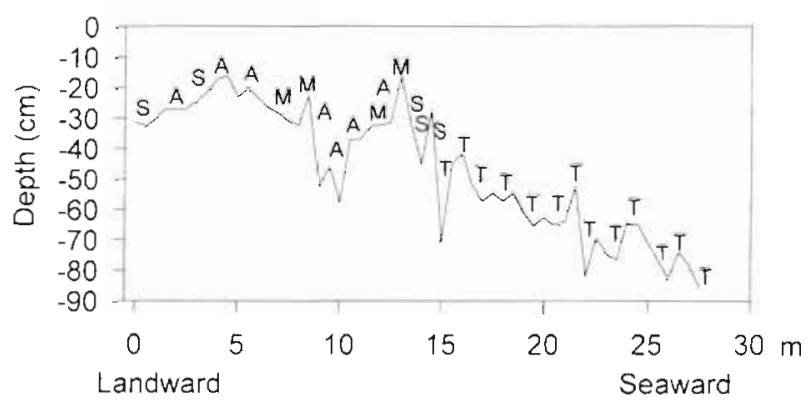

(A) Algae (M) Mussels (S) P. scouleri (T) P. torreyi

Fig. 1. Bathymetric profile of one of the transects laid to estimate the cover of the different components of the landscape of the rocky intertidal community at Mesquitito beach, Baja California, Mexico. Letters on the bathymetric profile indicate which component of the landscape is dominant in cover

landscape (Fig. 2) showed the topmost portions of the rock outcrops to be denuded of macroscopic organisms, with algae (dominated by green and coralline algae) and mussels occupying the more elevated colonized sustrata. The upper limit of surfgrass distribution corresponded to $30 \mathrm{~cm}$ below mean low water level (MLWL), with Phyllospadix scouleri occupying significantly (2-way ANOVA, $\mathrm{p}<0.01)$ shallower zones than $P$. torreyi (Fig. 2), which extended to the subtidal (down to about $4 \mathrm{~m}$ below MLWL). The maximum cover of $P$. scouleri was $16 \pm 3.6 \%$ of the sustrata between 40 and $50 \mathrm{~cm}$ below MLWL, whereas $P$. torreyi showed continuous cover $(100 \%)$ at the deeper portions studied ( 80 to $90 \mathrm{~cm}$ below MLWL; Fig. 2).

Table 1. Mean \pm SE annual values of shoots size, shoot density, and standing biomass of Phyllospadix scouleri and $P$. torreyi in Mesquitito beach (Baja California). Differences between species and/or sampling months are indicated by the corresponding ANOVA $F$ values and associated $\mathrm{p}$ values. Correlation coefficients between the mean value for each sampling month and the exposure to air during daytime hours are also included, ${ }^{\text {ns }}$ Not significant $(p>0.05) ; p<0.05, \cdots p<0.01$

\begin{tabular}{|c|c|c|c|c|c|c|c|}
\hline \multirow[t]{2}{*}{ Variable } & \multirow[t]{2}{*}{ Species } & \multirow[t]{2}{*}{ Mean $\pm \mathrm{SE}$} & \multirow[t]{2}{*}{ Range } & \multicolumn{3}{|c|}{ ANOVA results } & \multirow{2}{*}{$\begin{array}{c}\text { Correl } \\
\text { coeff. } \\
\text { r }\end{array}$} \\
\hline & & & & $\begin{array}{c}\text { Species } \\
F\end{array}$ & $\begin{array}{c}\text { Time } \\
F\end{array}$ & $\begin{array}{c}\text { Species } \times \text { Time } \\
F\end{array}$ & \\
\hline $\begin{array}{l}\text { Shoot size } \\
\left(\text { my DW leaves shoot }{ }^{-1} \text { ) }\right.\end{array}$ & $\begin{array}{l}\text { P. scouleri } \\
\text { P. torreyi }\end{array}$ & $\begin{array}{l}52.67 \pm 10.43 \\
80.63 \pm 7.79\end{array}$ & $\begin{array}{l}34.37-106.26 \\
61.67-108.90\end{array}$ & $53.49 \cdots$ & $18.09^{\cdots}$ & $10.44^{\cdots}$ & $\begin{array}{l}0.30^{\mathrm{ns}} \\
0.37^{\mathrm{ns}}\end{array}$ \\
\hline$\left(\mathrm{cm}\right.$ leaves shoot $\left.{ }^{-1}\right)$ & $\begin{array}{l}\text { P. scouleri } \\
\text { P. torreyi }\end{array}$ & $\begin{array}{r}77.18 \pm 6.19 \\
102.99 \pm 7.66\end{array}$ & $\begin{array}{l}54.81-104.95 \\
77.96-138.60\end{array}$ & $46.61^{\cdots}$ & $9.92 \cdots$ & $10.59 \cdots$ & $\begin{array}{r}-0.51^{\mathrm{ns}} \\
0.25^{\mathrm{ns}}\end{array}$ \\
\hline $\begin{array}{l}\text { Shoot density } \\
\text { (shoots } \mathrm{m}^{-2} \text { ) }\end{array}$ & $\begin{array}{l}\text { P. scouleri } \\
\text { P. torreyi }\end{array}$ & $\begin{array}{l}8472 \pm 541 \\
6759 \pm 618\end{array}$ & $\begin{array}{l}5750-9633 \\
4850-9050\end{array}$ & $6.35^{\circ}$ & $3.00^{\circ}$ & $0.72^{n s}$ & $\begin{array}{l}-0.01^{\mathrm{ns}} \\
-0.04^{\mathrm{ns}}\end{array}$ \\
\hline Biomass (g DW m $\mathrm{m}^{-2}$ ) & & & & & & & \\
\hline $\begin{array}{l}\text { Leaves } \\
\text { Sheaths } \\
\text { Rhizome plus roots }\end{array}$ & P. scouleri & $\begin{array}{l}364.7 \pm 37.7 \\
250.5 \pm 27.6 \\
418.1 \pm 49.9\end{array}$ & $\begin{array}{l}198.3-516.67 \\
111.6-304.5 \\
224.4-555.9\end{array}$ & $\begin{array}{l}0.11^{\mathrm{ns}} \\
1.75^{\mathrm{ns}} \\
3.88^{\circ}\end{array}$ & $\begin{array}{l}5.78^{\circ} \\
2.69^{\circ} \\
3.46^{\circ}\end{array}$ & $\begin{array}{l}2.24^{\mathrm{ns}} \\
1.19^{\mathrm{ns}} \\
1.87^{\mathrm{ns}}\end{array}$ & $\begin{array}{r}-0.31^{\mathrm{ns}} \\
-0.22^{\mathrm{nis}} \\
0.09^{\mathrm{ns}}\end{array}$ \\
\hline $\begin{array}{l}\text { Leaves } \\
\text { Sheaths } \\
\text { Rhizome plus roots }\end{array}$ & P. torreyi & $\begin{array}{l}379.0 \pm 70.5 \\
207.4 \pm 29.1 \\
485.9 \pm 117.7\end{array}$ & $\begin{array}{l}123.3-588.3 \\
110.0-299.2 \\
146.0-909.3\end{array}$ & & & & $\begin{array}{l}-0.82 \\
-0.91^{\circ} \\
-0.14^{\text {ns }}\end{array}$ \\
\hline
\end{tabular}



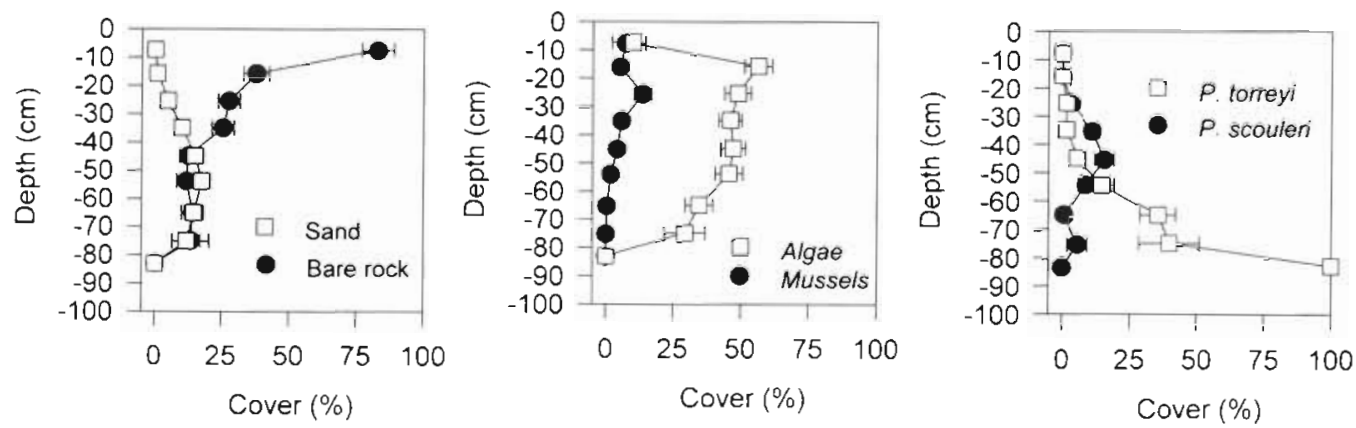

Fig. 2. Mean percent cover of each of the components of the landscape of the rocky intertidal community at Mesquitito beach (Baja California) at different depth intervals $(10 \mathrm{~cm}$ classes). The mean values and standard errors were calculated by pooling the 8 transects sampled between February and June 1997, after examination of the individual transects confirmed the absence of seasonal changes. Depth is shown relative to mean low sea level. Error bars represent $\pm 1 \mathrm{SE}$

The shoots and the individual leaves of Phyllospadix torreyi were larger than those of $P$. scouleri (Table 1), both species showed maximum size in August, with another peak observed in December for $P$. torreyi (Fig. 3). Leaf growth rates were greater $(p<0.01)$ for $P$. torreyi (Table 2), and reached maximal values in August for both species, when the air exposure of the studied area during daytime was shortest (Fig. 3). Conversely, shoot growth tended to be low for both species during April, the time of longest exposure to air (Fig. 3). P scouleri produced new leaves faster than $P$. torreyi (Table 2), both showing the slowest rate of production of new leaves in April (Fig. 3), when the daytime exposure of the studied area was longest. These rates result in an annual leaf production of $17.8 \pm 2.2$ and $22.6 \pm 2.2$ leaves per shoot of $P$. torreyi and $P$. scouleri, respectively.

Shoot density was greater for Phyllospadix scouleri than for $P$. torreyi and showed a parallel seasonal pattern (Table 1) involving low density in winter and maximal density in the spring and summer (Fig. 4). Both species had a similar biomass of leaves, leaf sheaths and rhizomes plus roots (Table 1, Fig. 4). The biomass of aboveground material (59.7 \pm 5.5 and $56.4 \pm 2.5 \%$ of the biomass for $P$. scouleri and $P$. torreyi, respectively) exceeded that of rhizomes plus roots, which nevertheless had a large contribution to the biomass of both species. Surfgrass biomass was lowest in April, and showed parallel seasonal patterns for both species (Fig. 4). The reproductive period of surfgrass started in spring and extended over the summer, with the flowers of both species reaching a comparable biomass (Fig. 4). Despite the profusion of flowers in summer, virtually all flowers appeared in female clones, with male flowers being present rather infrequently.

The production of surfgrass (including leaves, sheaths, rhizome and roots) in the study area was very high, far exceeding $8000 \mathrm{~g} \mathrm{DW} \mathrm{m}^{-2} \mathrm{yr}^{-1}$ in areas with continuous cover of the seagrass. However, only Phyl-
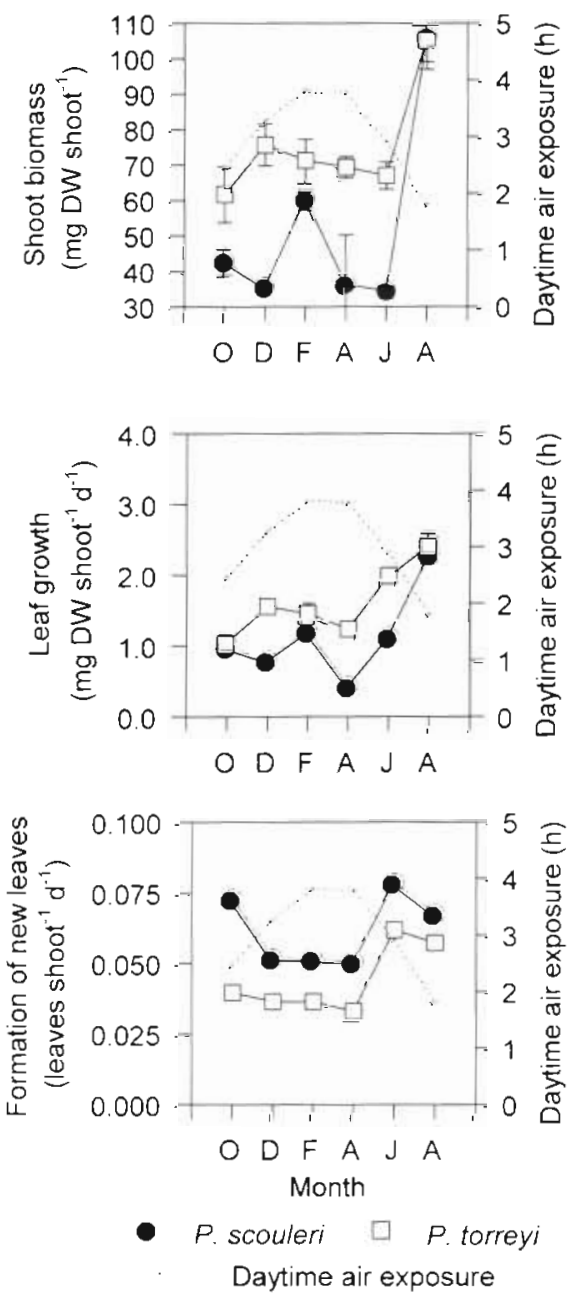

Fig. 3. Mean biomass, leaf growth, and rate of formation of new leaves of shoots of Phyllospadix torreyi and P. scouleri in Mesquitito beach (Baja California). Dotted line represents the duration of exposure to air during daytime at the $-36 \mathrm{~cm}$ depth. Error bars represent $\pm 1 \mathrm{SE}$ 
Table 2. Mean \pm SE annual values of leaf growth, formation of new leaves and production of Phyllospadix scouleri and $P$. torreyi in Mesquitito beach (Baja California). Differences between species and/or sampling months are indicated by the corresponding ANOVA $F$ values and associated $p$ values. Correlation coefficients between the mean value for each sampling month and the exposure to air during daytime hours are also included. ${ }^{\text {ns Not significant }(p>0.05) ;}$; $<<0.05, \cdots p<0.01$

\begin{tabular}{|c|c|c|c|c|c|c|c|}
\hline \multirow[t]{2}{*}{ Variable } & \multirow[t]{2}{*}{ Species } & \multirow[t]{2}{*}{ Mean $\pm \mathrm{SE}$} & \multirow[t]{2}{*}{ Range } & \multicolumn{3}{|c|}{ ANOVA results } & \multirow{2}{*}{$\begin{array}{l}\text { Correl. } \\
\text { coeff. } \\
r\end{array}$} \\
\hline & & & & $\begin{array}{c}\text { Species } \\
F\end{array}$ & $\begin{array}{c}\text { Time } \\
F\end{array}$ & $\begin{array}{c}\text { Species } \times \text { Time } \\
F\end{array}$ & \\
\hline $\begin{array}{l}\text { Leaf growth rate } \\
\text { (mg DW leaves shoot }{ }^{-1} \mathrm{~d}^{-1} \text { ) }\end{array}$ & $\begin{array}{l}\text { P. scouleri } \\
\text { P. torreyi }\end{array}$ & $\begin{array}{l}1.14 \pm 0.23 \\
1.62 \pm 0.19\end{array}$ & $\begin{array}{l}0.44-2.30 \\
1.06-2.44\end{array}$ & $64.43^{\prime}$ & $46.07^{\cdots}$ & $6.37^{\cdots}$ & $\begin{array}{r}0.76^{\mathrm{ns}} \\
-0.58^{\mathrm{ns}}\end{array}$ \\
\hline (cm leaves shoot ${ }^{-1} \mathrm{~d}^{-1}$ ) & $\begin{array}{l}\text { P. scouleri } \\
\text { P. torreyi }\end{array}$ & $\begin{array}{l}1.72 \pm 0.19 \\
2.04 \pm 0.11\end{array}$ & $\begin{array}{l}0.90-2.47 \\
1.62-2.35\end{array}$ & $35.18 \cdot$ & $20.11^{\prime}$ & $13.84^{\bullet \cdot}$ & $\begin{array}{l}-0.87^{\circ} \\
-0.24^{\mathrm{ns}}\end{array}$ \\
\hline $\begin{array}{l}\text { Rate of formation of new } \\
\text { leaves (leaves shoot }{ }^{-1} \mathrm{~d}^{-1} \text { ) }\end{array}$ & $\begin{array}{l}\text { P. scouleri } \\
\text { P. torreyi }\end{array}$ & $\begin{array}{l}0.0621 \pm 0.0046 \\
0.0493 \pm 0.0046\end{array}$ & $\begin{array}{l}0.0504-0.0785 \\
0.0329-0.0619\end{array}$ & $0.82^{\mathrm{ns}}$ & & & $\begin{array}{l}-0.70^{\mathrm{ns}} \\
-0.19^{\mathrm{ns}}\end{array}$ \\
\hline \multicolumn{8}{|l|}{ Production (g DW $\mathrm{m}^{-2} \mathrm{~d}^{-1}$ ) } \\
\hline $\begin{array}{l}\text { Leaves } \\
\text { Sheaths } \\
\text { Rhizome plus roots }\end{array}$ & P. scouleri & $\begin{array}{r}9.65 \pm 1.96 \\
4.08 \pm 0.76 \\
10.57 \pm 1.39\end{array}$ & $\begin{array}{l}4.08-18.61 \\
1.27-6.65 \\
6.09-15.47\end{array}$ & $\begin{array}{l}3.67^{\mathrm{ns}} \\
5.78^{-} \\
0.12^{\mathrm{ns}}\end{array}$ & $\begin{array}{r}24.89^{\cdots} \\
9.64^{\cdots} \\
4.03^{\cdots}\end{array}$ & $\begin{array}{l}3.51 \cdots \\
1.51^{\mathrm{ns}} \\
1.49^{\mathrm{ns}}\end{array}$ & $\begin{array}{l}-0.75^{\mathrm{ns}} \\
-0.48^{\mathrm{ns}} \\
-0.53^{\mathrm{ns}}\end{array}$ \\
\hline $\begin{array}{l}\text { Leaves } \\
\text { Sheaths } \\
\text { Rhizome plus roots }\end{array}$ & P. torreyi & $\begin{array}{r}11.18 \pm 1.90 \\
3.01 \pm 0.57 \\
11.34 \pm 1.41\end{array}$ & $\begin{array}{l}5.76-19.09 \\
1.12-4.55 \\
6.94-15.93\end{array}$ & & & & $\begin{array}{l}-0.51^{\mathrm{ns}} \\
-0.91^{\cdots} \\
-0.25^{\mathrm{ns}}\end{array}$ \\
\hline
\end{tabular}
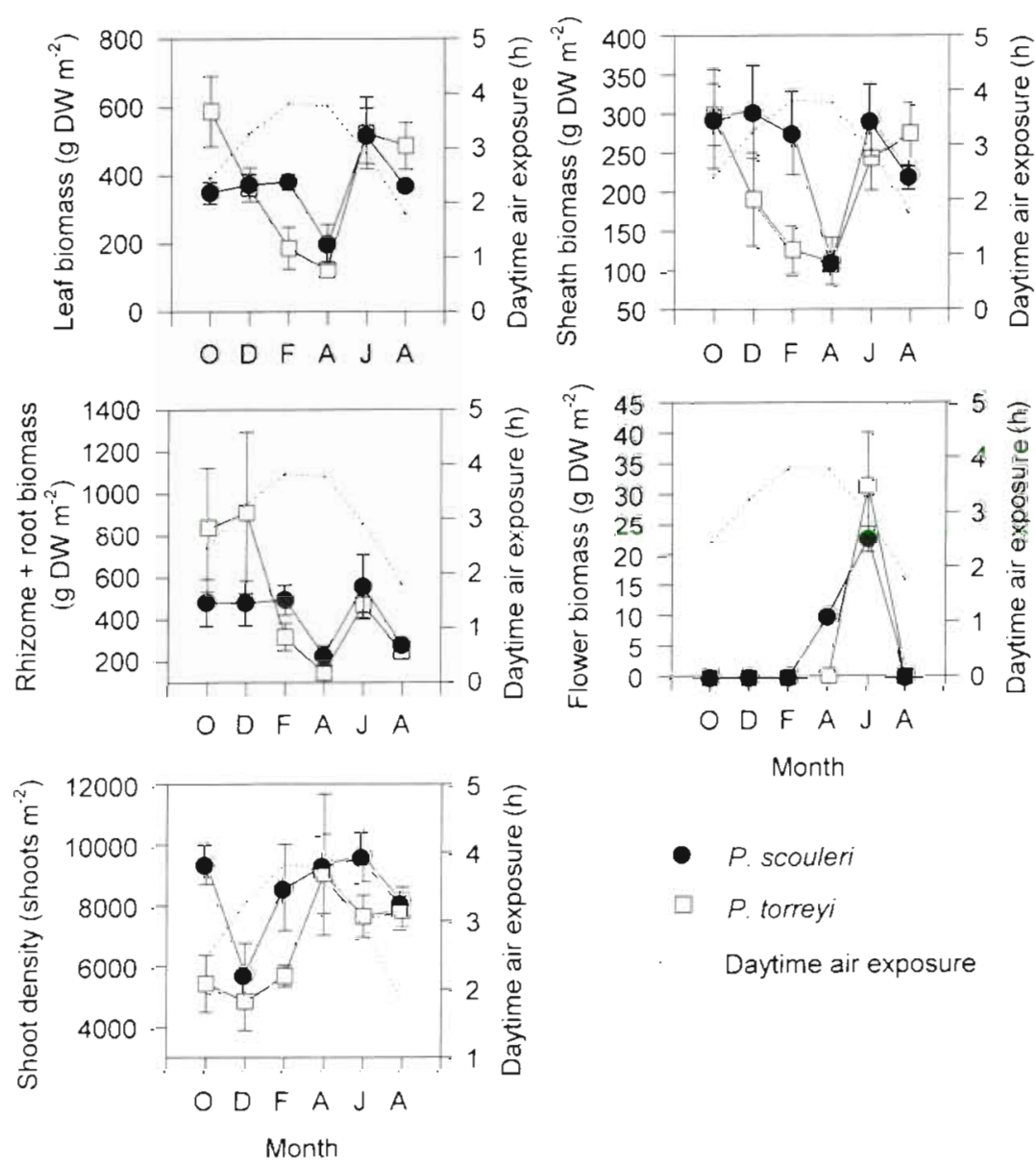

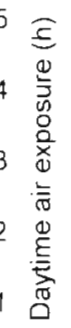

lospadix torreyi reached a $100 \%$ cover of the sustratum, whereas the maximum cover of $P$. scouleri did not exceed $16 \%$, so that the annual production of $P$, scouleri did not exceed $1330 \mathrm{~g} \mathrm{DW} \mathrm{m}^{-2} \mathrm{yr}^{-1}$, when the extent of its cover is considered. Because of the $1: 1$ relationship between production of new leaves and that of rhizome internodes, rhizome production was very high, often exceeding that of leaves (Fig. 5). The elongation of tagged rhizomes provided estimates of rhizome elongation rates averaging 0.47 (October to December) and 0.24 (October to August) $\mathrm{mm} \mathrm{d}^{-1}$ for $P$. torreyi, and $0.58 \mathrm{~mm} \mathrm{~d}^{-1}$ (July to August) for $P$. scouleri. The results obtained for $P$. torreyi indicate that late fall to early winter rhizome growth rates are about twice as high as the annual average growth rate.

Fig. 4. Mean biomass of leaves, sheaths, rhizome plus roots, and flowers, and shoot density of Phyllospadix torreyi and $P$. scouleri in Mesquitito beach (Baja Californial. Dotted line represents the duration of exposure to air during daytime at the $-36 \mathrm{~cm}$ depth. Error bars represent

$$
\pm 1 \mathrm{SE}
$$



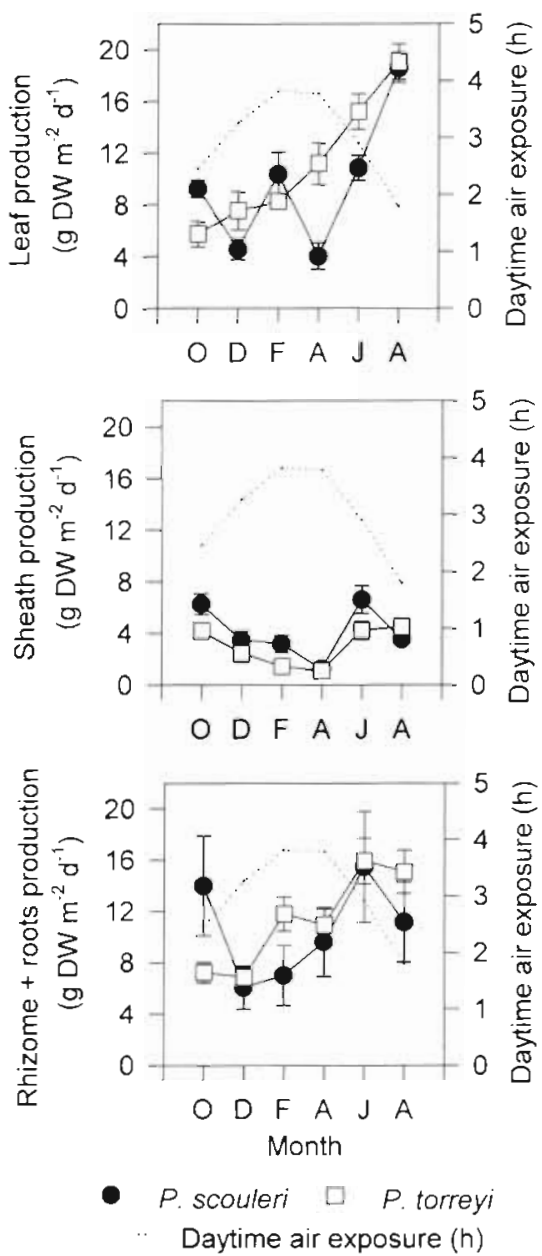

Fig. 5. Mean production of leaves, sheaths and rhizome plus roots of Phyllospadix torreyi and P. scouleri in Mesquitito beach (Baja California). Dotted line represents the duration of exposure to air during daytime at the $-36 \mathrm{~cm}$ depth. Error bars represent $\pm 1 \mathrm{SE}$

The inferred annual growth rate of the rhizome of $P$. torreyi would be $8.76 \mathrm{~cm} \mathrm{yr}^{-1}$. Rhizome growth demanded a similar allocation of resources for $P$. scouleri and $P$. torreyi (44.8\% of total production). Surfgrass production tended to be lower from winter to early spring, and was high during the summer and fall (Fig. 5). There were, however, significant differences between the seasonal patterns observed for both species (Table 2), with areal leaf production declining more in April, the time of longer air exposure, for $P$. scouleri.

Examination of correlation coefficients between the different components of the biomass and production of surfgrass and the length of exposure to air during daytime revealed a consistent tendency towards a decline in biomass and growth during periods of long exposure (Tables $1 \& 2$ ). Even if many of these correlation coefficients are not statistically significant, due to the limited
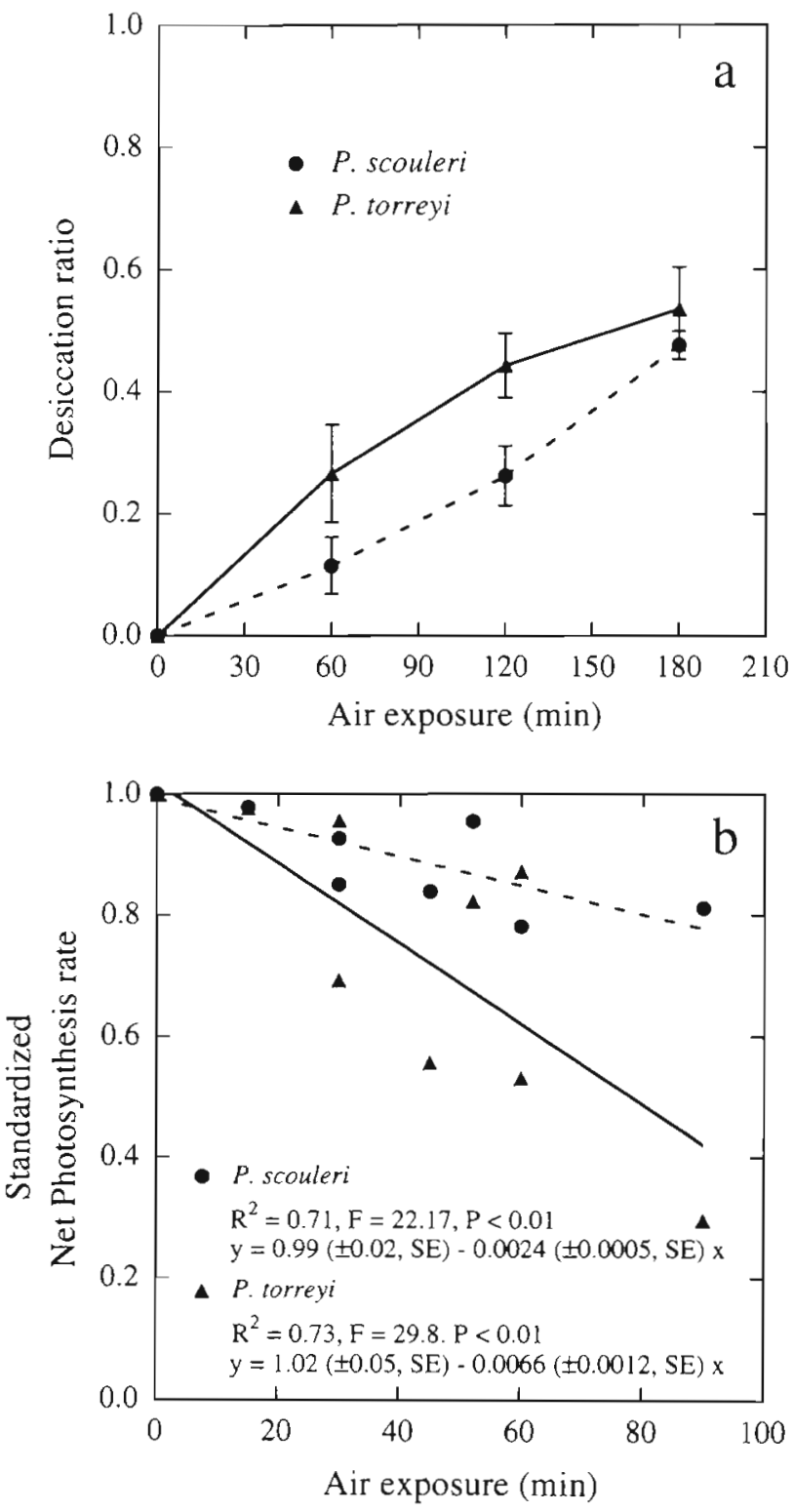

Fig. 6. Effects of the duration of air exposure on (a) leaf desiccation and (b) net photosynthesis of Phyllospadix scouleri and

$P$. torreyi. Error bars in (a) represent $\pm 1 \mathrm{SE}$

number of sampling visits, most of them are negative, strongly pointing to an overall negative relationship between exposure to air and surfgrass performance, as evidenced by a significant ( $p<0.025$ ) overall correlation between surfgrass biomass and production and the exposure to air during daytime.

Phyllospadix torreyi desiccated faster than $P$. scouleri in the same environmental conditions, as evidenced by the higher $(t$-test, $t=2.51, \mathrm{p}<0.05)$ values of the desiccation ratio in the former species after $2 \mathrm{~h}$ of exposure to air (Fig. 6a). The desiccation of both surfgrass species was, however, similar after $3 \mathrm{~h}$ of air 
exposure. Air exposure was detrimental for surfgrass photosynthesis as indicated by significant ( $p<0.01$ ) negative slopes of the linear regressions between the standardized net photosynthesis rate and the duration of the exposure to air for both species after rehydratation of the shoots (Fig. 6b). The slope was more negative ( $t$-test, $t=3.22, p<0.05$ ) for $P$. torreyi than for $P$. scouleri, which indicates that the net photosynthesis of $P$. torreyi was more affected by air exposure than that of $P$. scouleri

The size of Phyllospadix scouleri shoots was not affected by the relocation of plants to either the intertidal or the subtidal. Both the length of the longest leaf in the shoot and the shoot biomass almost doubled during the experiment (Fig. 7 , Table 3). There were differences between the shoots in boulders assigned to the intertidal and subtidal positions at the onset of the experiment, and these differ-
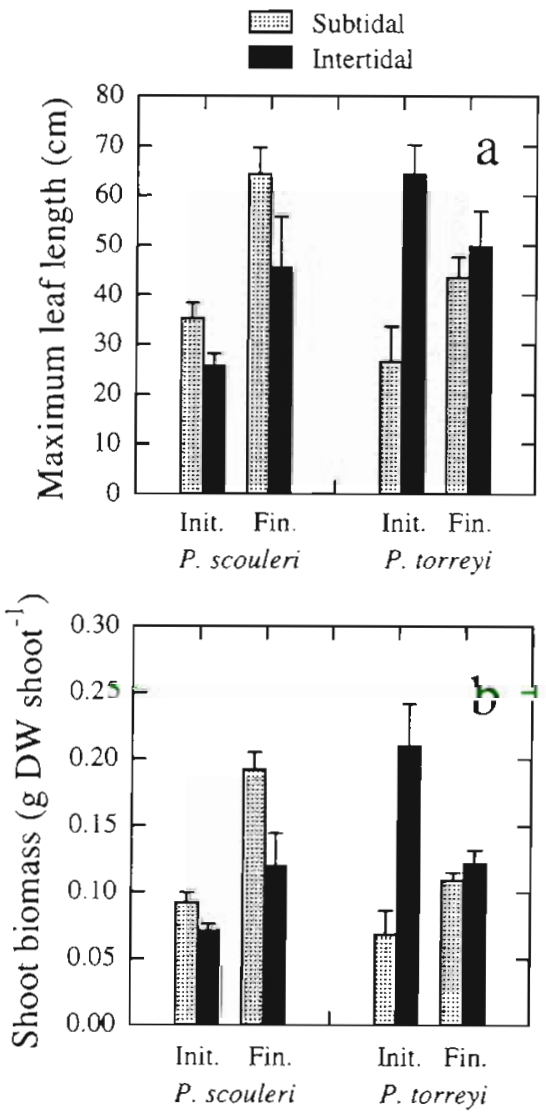

Fig. 7. Effects of the relocation of Phyllospadix scouleri and $P$. torreyi to 2 different levels of air exposure (subtidal, intertidal) on (a) the length of the longest leaf in the shoot and (b) shoot biomass. Init: the values of these variables at the onset of the experiment; Fin.: the values after $77 \mathrm{~d}$. Error bars represent $\pm 1 \mathrm{SE}$
Table 3. Summary of results of the 2-way ANOVAs performed to test for the effect of the level of exposure to air on the size of surfgrass shoots. $\cdot p<0.05, \cdots p<0.01 ;{ }^{n s}$ not significant ( $\left.p>0.05\right)$

\begin{tabular}{|c|c|c|c|}
\hline & $\begin{array}{c}\text { Time } \\
F\end{array}$ & $\begin{array}{c}\text { Exposure } \\
F\end{array}$ & Time $\times$ Exposure \\
\hline \multicolumn{4}{|l|}{ Phyllospadix scouleri } \\
\hline Maximum leaf length $(\mathrm{cm})$ & $16.11 \cdots$ & $5.43^{\circ}$ & $0.57^{\mathrm{ns}}$ \\
\hline Shoot biomass (g DW shoot ${ }^{-1}$ ) & $24.82^{\cdots}$ & $9.86^{\circ}$ & $2.95^{\mathrm{ns}}$ \\
\hline \multicolumn{4}{|l|}{ Phyllospadix torreyi } \\
\hline Maximum leaf length $(\mathrm{cm})$ & $0.03^{\text {ns }}$ & $10.73^{\circ}$ & $5.49^{\text {ns }}$ \\
\hline Shoot biomass (g DW shoot ${ }^{-1}$ ) & $0.97^{\mathrm{ns}}$ & $10.45^{\circ}$ & $7.33^{\circ}$ \\
\hline
\end{tabular}

ences were maintained throughout it. The length of the longest leaf in the shoot and shoot biomass were not affected by the different levels of air exposure, as evidenced by a non-significant Time $\times$ Exposure interaction (Fig. 7, Table 3). The size of $P$. torreyi shoots was, however, affected by the level of air exposure: both the length of the longest leaf in the shoot and shoot biomass decreased during the experiment in the intertidal position while they increased in the subtidal positions (Fig. 7), as evidenced by a significant Time $x$ Exposure interaction for shoot biomass, and a marginally significant $(p=0.0576)$ interaction for the length of the longest leaf in the shoot (Table 3). Again, there were differences between the shoots on boulders assigned to the intertidal and subtidal positions at the onset of the experiments, but these differences became smaller at the end of the experiment (Fig. 7). The number of leaves per shoot and the width of the leaves were not affected by the level of exposure to air (data not shown)

\section{DISCUSSION}

The patchy nature of the intertidal landscape studied results from the complex topography of the rocky platforms together with a significant bathymetric differentiation of the landscape components. The most elevated portions of the rocks were devoid of macroscopic organisms and only mussels and coralline algae developed significant cover 10 to $20 \mathrm{~cm}$ below the highest features of the landscape. Coralline algae are known to be remarkably tolerant to air exposure (Seapy \& Littler 1982), both through physiological mechanisms and from protection derived from sand trapped within their thalli (Littler \& Littler 1980, Stewart 1983). Mussels are also highly resistant to exposure to air because they can maintain their valves closed for long periods of time, even switching to anaerobic metabolism if necessary, thereby avoiding desiccation (Bayne et al. 1976 
Seapy \& Littler 1982). Surfgrass, however, only achieves substantial cover in the lower reaches of the intertidal (Turner 1985, Turner \& Lucas 1985).

The results presented confirm previous observations that surfgrass species are bathymetrically differentiated, with Phyllospadix scouleri reaching its highest cover some 30 to $40 \mathrm{~cm}$ above the level where $P$. torreyi reached its maximum cover. Moreover, the maximum cover reached by $P$. scouleri did not exceed $16 \%$, on average, at any given depth range, whereas $P$. torreyi achieved complete cover $(100 \%)$ in the deeper zone where it grew. The cover observed for $P$. scouleri is similar to that reported for intertidal populations in California and Oregon (Horn et al. 1983, Turner 1985, Turner \& Lucas 1985), whereas $P$. torreyi often produces closed canopies in the subtidal (e.g. Williams 1995) which can extend to the lower limit of the intertidal, as observed here. The association of closed canopies of surfgrass with the lowest level of the intertidal is so close that continuous surfgrass carpets are considered to be reliable indicators of the mean lower low water level (Ricketts et al. 1985).

Phyllospadix torreyi was more affected by the exposure to air than $P$. scouleri. First, the leaves of $P$. torreyi desiccated more than those of $P$. scouleri under the same conditions of air exposure. Second, the photosynthetic activity of both species was negatively affected by the exposure to air, but $P$. torreyi showed a larger reduction of the net photosynthesis rate than $P$. scouleri after air exposure of the same duration. Altogether, these results provide a mechanism to explain the bathymetric differentiation of these 2 surfgrass species in the intertidal, with $P$. torreyi being more sensitive to air exposure than $P$. scouleri. Hence, the transplant experiment performed showed that, under a regime of air exposure at which only $P$. scouleri occurs, the size (biomass, leaf length) of $P$. torreyi shoots decreased while that of $P$. scouleri increased, which suggests that the negative effects of air exposure on the photosynthetic activity of $P$. torreyi result in detrimental consequences for its vegetative development.

Phyllospadix torreyi produced larger shoots and longer leaves that $P$. scouleri, which is consistent with previous observations (McMillan \& Phillips 1981). Yet, both species tend to develop remarkably similar biomasses, which varied along the studied period, displaying the lowest biomass in April, the time of longest exposure to the air. Non-photosynthetic tissues (rhizomes plus roots) had an important contribution (about $40 \%$ ) to surfgrass biomass. Previous studies have shown the relative biomass allocated to photosynthetic versus non-photosynthetic tissues to decline towards the high elevations of the intertidal, with rhizomes plus roots contributing a much greater percentage of the biomass in plants located towards the shallow depth limit of the plants (Stewart 1989). Indeed, these species have been found to produce shoots larger than those reported here when growing subtidally (Williams 1995)

The rate of formation of new leaves, which also corresponds to that of new internodes, proceeded at a relatively uniform pace through the study, with shoots of Phyllospadix scouleri producing a greater number of leaves per year than those of $P$. torreyi. The values reported are, to our knowledge, the first estimates derived for these species. However, information on Asian Phyllospadix iwatensis indicates shoots of this species form a new leaf every $19.8 \mathrm{~d}$ (Yabe et al. 1996), similar to those we report for the American Phyllospadix species. Leaves elongated at rates of about $2 \mathrm{~cm} \mathrm{shoot}^{-1} \mathrm{~d}^{-1}$ for both species, $30 \%$ slower than those reported for subtidal $P$. torreyi stands (Williams 1995).

The few reports on surfgrass rhizome elongation rates available point to a significant plasticity in this key trait (2 to $6 \mathrm{~cm} \mathrm{yr}^{-1}$ for Phyllospadix scouleri [Turner 1985]; about $50 \mathrm{~cm} \mathrm{yr}^{-1}$ [Stewart 1989] or 8.7 $\mathrm{cm} \mathrm{yr}^{-1}$ [this study] for $P$. torreyi). There is, however, consensus that disturbed surfgrass patches recover in less than 3 to 4 yr (Dethier 1984, Turner 1985, Stewart 1989); this recovery should proceed mainly by clonal growth because the occupation of surfgrass habitat by sexual reproduction seems to be highly inefficient (Dethier 1984, Turner 1985, Williams 1995). Disturbance is considered a major factor in the ecology of surfgrass (e.g. Dethier 1984, Turner 1985), whereby surfgrass patches may die-off due to air exposure or be pulled off during storms, which might partially account for the patchy distribution of surfgrass and the mosaic appearance of the landscape in the rocky intertidal of the study area.

Recent reports for Asian congeneric species occupying similar habitats suggest surfgrass to be a fastgrowing species (Yabe et al. 1995, 1996), being able to support productive meadows. American surfgrass developed very dense (>6000 shoots $\mathrm{m}^{-2}$ ) stands, which, coupled to their substantial leaf production, resulted in highly productive meadows. The aboveground production of stands of both species matched the highest values previously reported for any seagrass species (4619 g DW m $\mathrm{g}^{-2} \mathrm{yr}^{-1}$, Halodule wrightii; Gallegos et al. 1994), whereas surfgrass rhizome production rates were up to 4 times higher than previously reported maximum values $\left(4 \mathrm{~g} \mathrm{DW} \mathrm{m}^{-2} \mathrm{~d}^{-1}\right.$, Zostera marina; Pedersen $\&$ Borum 1992) for any seagrass species. Yet, all the evidence presented above on bathymetric distribution of the species, as well as their shoot size and stand biomass, suggests that the plants were stressed due to exposure to air in the intertidal environment. Indeed, examination of biomass, growth and 
production of photosynthetic tissues of Phyllospadix torreyi revealed these traits to be significantly reduced during periods of long exposure to air during daytime. Our results suggests $P$. torreyi to be more sensitive to desiccation than $P$. scouleri is, accounting for their bathymetric distribution and the restriction of $P$. torreyi to the seaward limit of the intertidal shore and to deep pools within the upper reaches of the intertidal, where it dominates seagrass biomass. This points to exposure to air during low tide as the most influential factor affecting the growth performance and production of intertidal surfgrass. Moreover, surfgrass displays a peculiar seasonality compared to other temperate species, which all have maximum growth in late spring. Surfgrass growth and production was, however, minimal in spring, coinciding with the longest exposure to air.

In summary, the results presented show that surfgrass communities rank amongst the most productive communities on the planet. The observation of very high primary production in the high-energy environment surfgrass inhabits supports contentions that turbulence is a major factor in the control of primary production in the sea (Margalef 1997). Yet, the environment occupied by surfgrass is also a stressing one, where plants are subject to frequent disturbance allowing for the occupation of the space by fastergrowing communities (Turner 1985, Turner \& Lucas 1985), and where the stress associated with air exposure sets narrow limits to surfgrass distribution.

Acknowledgements. This research was funded by Consejo Nacional de Ciencia y Tecnología (project $0074 \mathrm{P}-\mathrm{N}$ ), and by Dirección General de Asuntos del Personal Académico (project IN203596), Universidad Nacional Autónoma de Mexico (UNAM), and a cooperative research project between the Consejo Superior de Investigaciones Cientificas (Spain) and CONACYT (Mexico). N.S.R.A. was supported by the Spanish Agency for International Cooperation (AECI), and J.T. by the Spanish Ministry of Education and Culture. We thank Juan Fuentes for his help in the field and the lab, Dr Silvia Ibarra and the staff at her laboratory for their support in the realization of the study, Jorge Reyes for his assistance with the tide data, and Centro de Investigación Científica y de Educación Superior de Ensenada (CICESE), Baja California, for logistical support.

\section{LITERATURE CITED}

Barbour MG, Radosevich SR (1979) ${ }^{14} \mathrm{C}$ uptake by the marine angiosperm Phyllospadix scouleri. Am J Bot 66:301-306

Bayne BL, Bayne CJ, Carefoot TC. Thompson RJ (1976) The physiological ecology of Mytilus californianus Conrad. 2. Adaptations to low oxygen tension and air exposure. Oecologia 22:229-250

Brouns JJWM (1985) The plastochrone interval method for the study of the productivity of seagrasses; possibilities and limitations. Aquat Bot 21:71-88 den Hartog C (1970) The seagrasses of the world. North Holland Publ, Amsterdam

Dethier MN (1984) Disturbance and recovery in intertidal pools: maintenance of mosaic patterns. Ecol Monogr 54 : $99-118$

Duarte CM, Marbá N, Agawin NSR, Cebrián J, Enriquez S, Fortes MD, Gallegos ME, Merino M, Olesen B, SandJensen K, Uri JS, Vermaat JE (1994) Reconstruction of seagrass dynamics: age determinations and associated tools for the seagrass ecologist. Mar Ecol Prog Ser 107 : 195-209

Gallegos ME, Merino M, Rodriguez A, Marbà N, Duarte CM (1994) Growth patterns and demography of pioneer Canbbean seagrasses Halodule wrighti and Syringodium filiforme. Mar Ecol Prog Ser 109:99-104

García E (1988) Modificaciones al sistema de clasificación climática de Köppen. Offset Larios, SA, Mexico City

Horn MH, Murray SN, Seapy RR (1983) Seasonal structure of a Central California rocky intertidal community in relation to environmental variations. Bull South Calif Acad Sci 82: $79-94$

Kikuchi $T$ (1980) Faunal relationships in temperate seagrass beds. In: Phillips RC, McRoy CP (eds) Handbook of seagrass biology: an ecosystem perspective. Garland STPM, New York, p 153-172

Littler MM, Littler DS (1980) The evolution of thallus form and survival strategies in benthic marine macroalgae: field and laboratory test of a functional form model. Am Nat 310:694-695

Margalef R (1997) Turbulence and marine life. Scient Mar 61 109-123

McMillan C, Phillips RC (1981) Morphological variations and isozymes of North American Phyllospadix (Potamogetonaceae). Can J Bot 59:1494-1500

Pedersen MF, Borum J (1992) Nitrogen dynamics of eelgrass Zostera marina during a late summer period of high growth and low nutrient availability. Mar Ecol Prog Ser 80: $65-73$

Phillips RC (1979) Ecological notes on Phyllospadix (Potamogetonaceae) in the Northeast Pacific. Aquat Bot 6 $159-170$

Ricketts EG, Calvin J, Hedgpeth J, Phillips DW (1985) Between Pacific tides. Stanford University Press, Palo Alto, $\mathrm{CA}$

Seapy RR, Littler MM (1982) Population and species diversity fluctuations in a rocky intertidal community relative to severe aerial exposure and sediment burial. Mar Biol 71 . $87-96$

Sokal R, Rohlf FJ (1981) Biometry. The principles and practice of statistics in biological research. WH Freeman, New York

Stewart JG (1983) Fluctuations in the quantity of sediments trapped among algal thalli on intertidal rock platforms in Southern California. J Exp Mar Biol Ecol 73:205-211

Stewart JG (1989) Maintenance of a balanced, shifting boundary between the seagrass Phyllospadix and algal turf. Aquat Bot 33:223-241

Stewart JG, Rudenberg L (1980) Microsporocyte growth and meiosis in Phyllospadix torreyi, a marine monocotyledon Am J Bot 67:949-954

Terrados J, Williams SL (1.997) Leaf versus root nitrogen uptake by the surfgrass Phyllospadix torreyi S. Watson. Mar Ecol Prog Ser 149:267-277

Turner T (1985) Stability of rocky intertidal surfgrass beds persistence, preemption and recovery. Ecology 66(1) 83-92

Turner T, Lucas J (1985) Differences and similarities in the 
community roles of three rocky intertidal surfgrasses. J Exp Mar Biol Ecol 89:175-189

Williams SL (1995) Surfgrass (Phyllospadix torreyi) reproduction: reproductive phenology, resource allocation and male rarity. Ecology 76:1953-1970

Yabe T, Ikusima I, Tsuchiya T (1995) Production and population ecology of Phyllospadix iwatensis Makino. L. Leaf

Editorial responsibility: Otto Kinne (Editor),

Oldendorf/Luhe, Germany growth and biomass in an intertidal zone. Ecol Res 10: 291-299

Yabe T, Ikusima I, Tsuchiya T (1996) Production and population ecology of Phyllospadix iwatensis Makin. II. Comparative studies on leaf characteristics, foliage structure and biomass change in an intertidal and subtidal zone. Ecol Res 11:291-297

Submitted: February 18, 1998; Accepted: July 13, 1998 Proofs received from author(s): October 19, 1998 